\title{
ISOTOPIC STUDIES OF POTASSIUM METABOLISM IN DIABETES ${ }^{1,2}$
}

\author{
By JERRY K. AIKAWA, ${ }^{3}$ JOHN H. FELTS, JR., AND GEORGE T. HARRELL, JR. \\ WITH THE TECH ICAL ASSISTANCE OF ELOISE L. RHOADES \\ (From the North Carolina Baptist Hospital and the Department of Internal Medicine, Bowman \\ Gray School of Medicine of Wake Forest College, Winston-Salem, N. C.)
}

(Submitted for publication July 14, 1952; accepted October 1, 1952)

It is well recognized that deficits of cellular potassium and hypokalemia may develop in diabetic patients under treatment for acidosis and coma $(1,2)$. No data are available, however, concerning potassium metabolism in less severe stages of diabetes, in the presence of complications, or in diabetics with intercurrent disease. The availability of the artificial radioactive isotope, $\mathrm{K}^{42}$, has made possible a direct measurement of the "exchangeable body content" of potassium (3). The following study was performed in an attempt to measure and evaluate the exchangeable potassium content $(\mathrm{Ke})$ in diabetic patients at various stages of regulation and during treatment for various complications; and to determine the effect of orally administered potassium salts upon the body content of potassium.

\section{MATERIAL}

The subjects were 42 unselected diabetic patients-22 females and 20 males between the ages of 18 and 78 yearswho were hospitalized for regulation of the diabetes, for treatment of complications, or for causes unrelated to the diabetic condition. The cases varied widely in severity, duration and adequacy of control. One subject (case 9) was in acidosis and coma. All but two (cases 29 and 30) required insulin. Pertinent information concerning the clinical status of these $\mathbf{4 2}$ patients is given in Tables I and II.

The shipments of $\mathrm{K}^{23}$ were received on Monday and were treated in the manner described by Corsa and his co-workers (3). One and a half milliequivalents of potassium chloride solution, containing 100 microcuries of $\mathrm{K}^{42}$, was administered intravenously to those subjects in-

1 This work was supported in part by a grant-in-aid from the American Heart Association and in part by the U. S. Atomic Energy Commission under a contract with the Bowman Gray School of Medicine.

2 The $\mathrm{K}^{\text {sa }}$ was supplied by the National Laboratory, Oak Ridge, Tenn., on allocation from the U. S. Atomic Energy Commission.

3 Research Fellow of the American Heart Association sponsored by the 20-30 International Rheumatic Fever Foundation. jected on Tuesday. Three milliequivalents of potassium containing 100 microcuries of $\mathrm{K}^{\mathrm{s}}$ were injected into those subjects who were given the material on Wednesday.

\section{METHODS}

The initial determination of the exchangeable potassium content $(\mathrm{Ke}-1)$ was performed as soon as possible after the patient's admission to the hospital. Whenever possible, three serial determinations were performed at intervals of six to eight days. In all instances the usual routines of diabetic therapy, including diet, insulin and vitamin supplements, were followed.

In some cases, in order to determine the effect of an oral supplement on the body potassium content, potassium chloride, $1 \mathrm{Gm}$. thrice daily (a total of 40 milliequivalents of potassium daily), was given for one week after the initial determination of $\mathrm{Ke}(\mathrm{Ke}-1)$ was made. At the end of the week a second determination ( $\mathrm{Ke}-2)$ was made, and whenever possible a third determination ( $\mathrm{Ke}-3)$ was made one week later.

The technique used for the $\mathrm{Ke}$ determinations was as follows: The subject was given an intravenous injection of radioactive potassium by calibrated syringe between 7:30 and 9:00 a.m. All urine specimens until 7:00 a.m. on the following day were collected and pooled, and this collection of urine was measured for the excretion of $\mathrm{K}^{3}$. Specific activity of the urine was determined on two spot samples collected at 8 and 9 a.m. on the day after injection.

Preliminary studies confirmed the observation of Corsa and his associates (3) that the specific activity of $\mathrm{K}^{3}$ in the urine reached an equilibrium within 24 hours. The mean difference in specific activity between the two spot specimens, when expressed as percentage of the mean $\mathrm{Ke}$, was $6.52 \pm 6.65$ per cent. In normal individuals the administration of supplemental oral potassium, $3 \mathrm{Gm}$. daily for six days, resulted in a mean increase in $\mathrm{Ke}$ of 8.5 per cent; the maximum increase was 20.2 per cent in one male subject (4).

\section{Measurement of radioactivity}

The activity of the urine specimens was determined with a dipping tube and a scaling circuit. A total of 10,240 counts was made on all samples. All counting rates were at least ten times background, and were usually in the range of 500 to 3,000 per minute. At these counting rates, no correction for coincidence loss was necessary. All determinations were corrected for decay. 


\section{Chemical determinations}

The total inorganic potassium concentration in the urine was determined by flame photometry, using a method which has been described previously (5).

\section{Calculation of exchangeable potassium}

The following formula was used to calculate the value for the exchangeable potassium content of the body:

$$
\mathrm{Ke}=\frac{\mathrm{Ki}^{12}-\mathrm{Ko}^{12}}{\mathrm{Ku}^{12} / \mathrm{Ku}^{39}}
$$

$\mathrm{Ke}=$ quantity of exchangeable potassium in milliequivalents.

$\mathrm{Ki}^{\mathrm{is}}=$ quantity of radiopotassium administered (arbitrary units).

$\mathrm{K}_{\mathrm{O}^{42}}$ = quantity of radiopotassium excreted in the urine in the pooled specimen.
$\mathrm{Ku}^{\mathrm{i}}=$ concentration of radiopotassium in the spot samples.

$\mathrm{Ku}^{39}=$ concentration of inorganic potassium in the spot samples.

$\mathrm{Ku}^{12} / \mathrm{Ku}^{20}=$ mean specific activity of the two spot specimens.

\section{RESULTS}

A total of 72 determinations of $\mathrm{Ke}$ were made in the 42 subjects. In 22 individuals only a single determination was obtained. Serial determinations were made in 5 subjects who did not receive an oral supplement of potassium. In the remaining 15 cases supplemental potassium was given and two or more determinations of $\mathrm{Ke}$ were made.

TABLE I

Exchangeable potassium content in diabetic males

\begin{tabular}{|c|c|c|c|c|c|c|c|c|}
\hline Patient & Age & Weight & $\mathbf{K e}$ & $\begin{array}{c}\text { Change } \\
\text { in Ke }\end{array}$ & $\begin{array}{l}\text { Duration of } \\
\text { diabetes }\end{array}$ & State of disease & Complications & Incidental diseases \\
\hline \multicolumn{9}{|c|}{ Serial determinations with $\mathrm{KCl}$ supplement } \\
\hline 1 & 34 & $\begin{array}{l}60.9 \\
58.2 \\
58.2\end{array}$ & $\begin{array}{l}1923^{*} \\
2407 \dagger \\
2485 \ddagger\end{array}$ & $\begin{array}{l}+25.2 \\
+29.2\end{array}$ & 11 yrs. & $\begin{array}{l}\text { Out of regula- } \\
\text { tion } 3 \text { mos. }\end{array}$ & $\begin{array}{l}\text { Renal insuffi- } \\
\text { ciency and hyper- } \\
\text { tension }\end{array}$ & \\
\hline 2 & 40 & $\begin{array}{l}52.3 \\
48.3 \\
47.5 \\
47.3\end{array}$ & $\begin{array}{l}1553^{*} \\
1873 \dagger \\
1463 \ddagger \\
1985 \S\end{array}$ & $\begin{array}{l}+20.6 \\
-5.8 \\
+27.8\end{array}$ & 4 yrs. & Poor control & & $\begin{array}{l}\text { Duodenal ulcer, } 3 \text { mos. } \\
\text { Developed pyloric ob- } \\
\text { struction between Ke-2 } \\
\text { and } 3 \text {. Clinical potas- } \\
\text { sium deficiency with } \\
\text { Ke-3 }\end{array}$ \\
\hline 3 & 68 & $\begin{array}{l}76.1 \\
73.4\end{array}$ & $\begin{array}{l}2101^{*} \\
2404 \dagger\end{array}$ & +14.4 & 3 mos. & $\begin{array}{l}50 \text { lbs. wt. loss } \\
\text { in } 2 \text { yrs. }\end{array}$ & & \\
\hline 4 & 71 & $\begin{array}{l}61.1 \\
61.7 \\
60.9\end{array}$ & $\begin{array}{l}1544^{*} \\
1524 \dagger \\
1252^{\dagger}\end{array}$ & $\begin{array}{r}-1.3 \\
-18.9\end{array}$ & 3.5 yrs. & $\begin{array}{l}50 \text { lbs. wt. loss } \\
\text { in } 1 \text { yr. Dia- } \\
\text { betes easily } \\
\text { controlled }\end{array}$ & $\begin{array}{l}\text { Gangrene of toe, } \\
1 \text { yr. Supracon- } \\
\text { dylar amputation } \\
4 \text { days before } \mathrm{Ke}-3\end{array}$ & \\
\hline 5 & 66 & $\begin{array}{l}67.7 \\
65.9\end{array}$ & $\begin{array}{l}2441^{*} \\
2243 \dagger\end{array}$ & -8.1 & 2 wks. & Very mild & & $\begin{array}{l}\text { Benign prostatic hyper- } \\
\text { trophy. Prostatectomy } \\
\text { between Ke-1 and Ke-2 }\end{array}$ \\
\hline 6 & 46 & $\begin{array}{l}66.4 \\
66.4\end{array}$ & $\begin{array}{l}2146^{*} \\
2158 \dagger\end{array}$ & +.6 & 11 yrs. & Good control & $\begin{array}{l}\text { Gangrene of toes. } \\
\text { Supracondylar } \\
\text { amputation be- } \\
\text { tween Ke-1 and } \\
\mathrm{Ke}-2\end{array}$ & \\
\hline 7 & 77 & $\begin{array}{l}\mathbf{5 7 . 3} \\
\mathbf{5 7 . 3}\end{array}$ & $\begin{array}{l}1544^{*} \\
1735 \dagger\end{array}$ & +12.4 & $\begin{array}{l}\text { Diagnosed during } \\
\text { hospitalization }\end{array}$ & $\begin{array}{l}\text { Regulated } \\
\text { without diffi- } \\
\text { culty }\end{array}$ & & $\begin{array}{l}\text { Prostatic hypertrophy. } \\
\text { Arteriosclerotic heart } \\
\text { disease }\end{array}$ \\
\hline 8 & 72 & $\begin{array}{l}53.2 \\
53.2 \\
51.8\end{array}$ & $\begin{array}{l}1848 * \\
1750 \dagger \\
18947\end{array}$ & $\begin{array}{l}-5.3 \\
+2.5\end{array}$ & $\begin{array}{l}\text { Diagnosed during } \\
\text { hospitalization }\end{array}$ & Good control & $\begin{array}{l}\text { Gangrene of toes. } \\
\text { Supracondylar } \\
\text { amputation } 2 \\
\text { days after } \mathrm{Ke}-2\end{array}$ & $\begin{array}{l}\text { Arteriosclerotic heart } \\
\text { disease }\end{array}$ \\
\hline \multicolumn{9}{|c|}{ Serial determinations without $\mathrm{KCl}$ supplement } \\
\hline 9 & 49 & $\begin{array}{l}66.8 \\
66.8 \\
66.8\end{array}$ & $\begin{array}{l}1635 \\
2168 \\
2133\end{array}$ & $\begin{array}{l}+32.6 \\
+30.5\end{array}$ & 16 yrs. & $\begin{array}{l}\text { In acidosis and } \\
\text { coma with } \\
\text { Ke-1; conscious } \\
\text { after } 2 \text { days }\end{array}$ & $\begin{array}{l}\text { Renal disease. } \\
\text { Cerebral vascular } \\
\text { accident }\end{array}$ & \\
\hline
\end{tabular}


TABLE I-Continued

\begin{tabular}{|c|c|c|c|c|c|c|c|c|c|}
\hline Patient & Age & Weight & $\mathbf{K e}$ & $\begin{array}{l}\text { Change } \\
\text { in Ke }\end{array}$ & $\begin{array}{c}\text { Dura } \\
\text { dia }\end{array}$ & $\begin{array}{l}\text { ion of } \\
\text { petes }\end{array}$ & State of disease & Complications & Incidental diseases \\
\hline \multicolumn{10}{|c|}{ Single determinations } \\
\hline 10 & 23 & 39.5 & 1360 & & 7 yrs. & & Erratic control & & $\begin{array}{l}\text { Cirrhosis of liver by } \\
\text { aspiration biopsy. } \\
\text { Liver function tests } \\
\text { normal }\end{array}$ \\
\hline 11 & 35 & 57.3 & 954 & & 5 yrs. & & $\begin{array}{l}\text { Weight loss of } \\
70 \text { lbs. in } 5 \text { yrs. } \\
\text { Regulation in- } \\
\text { adequate }\end{array}$ & $\begin{array}{l}\text { Peripheral vascu- } \\
\text { lar disease and } \\
\text { neuropathy }\end{array}$ & \\
\hline 12 & 50 & 86.8 & 3383 & & 15 yrs. & & $\begin{array}{l}\text { Previously well } \\
\text { controlled }\end{array}$ & & Acute pneumonitis \\
\hline 13 & 58 & 45.8 & 2088 & & 3 yrs. & & Poor control & $\begin{array}{l}\text { Neuropathy, } \\
\text { obliterative } \\
\text { vascular disease }\end{array}$ & \\
\hline 14 & 48 & 107.7 & 3148 & & 14 yrs. & & Fair control & & Obesity \\
\hline 15 & 78 & 77.3 & 2092 & & $\begin{array}{l}\text { Diagnos } \\
\text { hospital }\end{array}$ & $\begin{array}{l}\text { d during } \\
\text { zation }\end{array}$ & & & $\begin{array}{l}\text { Recurrent urinary tract } \\
\text { infection with prosta- } \\
\text { titis. Arteriosclerotic } \\
\text { heart disease }\end{array}$ \\
\hline 16 & 59 & 87.0 & 2498 & & $\begin{array}{l}\text { Diagnos } \\
\text { hospital }\end{array}$ & $\begin{array}{l}\text { d during } \\
\text { zation }\end{array}$ & & & $\begin{array}{l}\text { Obesity, arterioscle- } \\
\text { rotic heart disease }\end{array}$ \\
\hline 17 & 67 & 74.3 & 2619 & & 5 yrs. & & $\begin{array}{l}\text { Well controlled. } \\
\text { Weight loss of } \\
20 \text { lbs. in } 1 \text { yr. }\end{array}$ & $\begin{array}{l}\text { Obliterative vas- } \\
\text { cular disease }\end{array}$ & Osteomyelitis \\
\hline 18 & 58 & 76.8 & 2160 & & 3 yrs. & & $\begin{array}{l}\text { Poor control. } \\
20 \text { lbs. wt. loss } \\
\text { in } 10 \text { mos. }\end{array}$ & & \\
\hline 19 & 45 & 77.3 & 4125 & & 15 yrs. & & $\begin{array}{l}35 \text { lbs. wt. loss } \\
\text { in } 2 \text { yrs. }\end{array}$ & & \\
\hline 20 & 65 & 77.3 & 2412 & & 7 mos. & & & $\begin{array}{l}\text { Neuropathy and } \\
\text { generalized } \\
\text { arteriosclerosis }\end{array}$ & \\
\hline
\end{tabular}

All Ke determinations were performed at weekly intervals unless otherwise noted.

* Ke-1, initial determination. $\quad+\mathrm{Ke}-3$, determination 1 wk. after $\mathrm{Ke}-2$.

$+\mathrm{Ke}-2$, determination after $\mathrm{KCl}, 3 \mathrm{gm}$. daily, for 6 days. $\quad$ Determination made $1 \mathrm{wk}$. after $\mathrm{Ke}-3$.

The clinical course of the subjects is described briefly in Tables I and II.

In order to determine whether the average $\mathrm{Ke} / \mathrm{wt}$. in an unselected group of hospitalized diabetic subjects differed from that in normal subjects (Figures 1 and 2), the mean initial $\mathrm{Ke} / \mathrm{wt}$. value was compared with the mean value in 50 normal subjects. The mean value for $\mathrm{Ke} / \mathrm{wt}$. was significantly lower in the male diabetics than in normal males. The difference between the mean $\mathrm{Ke} / \mathrm{wt}$. values for diabetic and normal women (6) was not significant. A possible cause of this sex difference is discussed below.
The results of the serial determinations of $\mathrm{Ke}$ were as follows:

In 5 of the 15 individuals who were given an oral supplement of potassium, the value for $\mathrm{Ke}$ increased by more than 20 per cent. Two of the 5 subjects not given an oral supplement showed an increase in Ke of more than 20 per cent. An attempt was made to correlate the clinical status of these patients with the response of $\mathrm{Ke}$ to the administration of oral potassium, or to the routine therapy. Of the 7 subjects, 6 gave a history of poor regulation of the diabetes prior to admission and the seventh had a history of poor dietary in- 
TABLE II

Exchangeable potassium content in diabetic females

\begin{tabular}{|c|c|c|c|c|c|c|c|c|}
\hline Patien & t Age & Weight & $\mathbf{K e}$ & $\begin{array}{c}\text { Change } \\
\text { in Ke }\end{array}$ & $\begin{array}{c}\text { Duration of } \\
\text { diabetes }\end{array}$ & State of disease & Complications & Incidental diseases \\
\hline \multicolumn{9}{|c|}{ Serial determinations with $\mathrm{KCl}$ supplement } \\
\hline 21 & 54 & $\begin{array}{l}50.4 \\
50.4\end{array}$ & $\begin{array}{l}1284^{*} \\
1945 \dagger\end{array}$ & +51.5 & 7 mos. & Poor control & & \\
\hline 22 & 52 & $\begin{array}{l}70.9 \\
68.2 \\
68.2\end{array}$ & $\begin{array}{r}918^{*} \\
2217 \ddagger \\
19548\end{array}$ & $\begin{array}{l}+141.5 \\
+112.9\end{array}$ & $13 \mathrm{yrs}$. & Fair control & $\begin{array}{l}\text { Neuropathy and } \\
\text { obliterative vas- } \\
\text { cular disease }\end{array}$ & Acute pyelonephritis \\
\hline 23 & 34 & $\begin{array}{l}51.4 \\
52.3\end{array}$ & $\begin{array}{l}1773^{*} \\
2320 \dagger\end{array}$ & +30.9 & 10 yrs. & $\begin{array}{l}35 \text { lbs. wt. loss } \\
\text { in } 2 \text { yrs. Er- } \\
\text { ratic control }\end{array}$ & & $\begin{array}{l}\text { Multiple sclerosis, } \\
8 \text { yrs. }\end{array}$ \\
\hline 24 & 45 & $\begin{array}{l}72.3 \\
72.3\end{array}$ & $\begin{array}{l}2456^{*} \\
2767 \dagger\end{array}$ & +12.7 & 7 yrs. & $\begin{array}{l}\text { Erratic control. } \\
\text { Well regulated } \\
\text { for } 2 \text { wks. be- } \\
\text { fore Ke-1 }\end{array}$ & & Acromegaly \\
\hline 25 & 62 & $\begin{array}{l}71.4 \\
69.3 \\
70.5\end{array}$ & $\begin{array}{l}1872 * \\
2062 \dagger \\
1836 \ddagger\end{array}$ & $\begin{array}{l}+10.1 \\
-1.9\end{array}$ & 6 yrs. & & $\begin{array}{l}\text { Neuropathy, } \\
\text { retinopathy, } \\
\text { hepatomegaly. } \\
\text { Ulcers of toes }\end{array}$ & \\
\hline 26 & 27 & $\begin{array}{l}54.8 \\
54.8\end{array}$ & $\begin{array}{l}1276^{*} \\
1313 \dagger\end{array}$ & +2.9 & 4 yrs. & $\begin{array}{l}\text { Very poor con- } \\
\text { trol. No recent } \\
\text { wt. loss }\end{array}$ & & \\
\hline 27 & 63 & $\begin{array}{l}43.9 \\
44.1 \\
44.1\end{array}$ & $\begin{array}{l}1368^{*} \\
1432 \dagger \\
1591 \ddagger\end{array}$ & $\begin{array}{r}+4.7 \\
+16.3\end{array}$ & 5 yrs. & $\begin{array}{l}\text { Poor control } \\
\text { prior to hos- } \\
\text { pitalization. } \\
8 \text { lbs. wt. loss } \\
\text { in } 6 \text { mos. }\end{array}$ & & \\
\hline \multicolumn{9}{|c|}{ Serial determinations without $\mathrm{KCl}$ supplement } \\
\hline 28 & 55 & $\begin{array}{l}68.6 \\
68.2\end{array}$ & $\begin{array}{c}927 \\
2267 \|\end{array}$ & +144.6 & 9 yrs. & $\begin{array}{l}\text { Fair control. } \\
\text { Poor dietary } \\
\text { intake }\end{array}$ & Ulcers of toes. & $\begin{array}{l}\text { Arteriosclerotic heart } \\
\text { disease }\end{array}$ \\
\hline 29 & 67 & $\begin{array}{l}56.9 \\
53.2 \\
53.2\end{array}$ & $\begin{array}{l}1469 \\
13569 \\
1333\end{array}$ & $\begin{array}{l}-7.7 \\
-9.3\end{array}$ & 6 yrs. & Fair control & & Coronary insufficiency \\
\hline 30 & 59 & $\begin{array}{l}72.7 \\
71.4\end{array}$ & $\begin{array}{l}1553 \\
1576\end{array}$ & +1.5 & 2 yrs. & $\begin{array}{l}\text { Diabetic glucose } \\
\text { tolerance curve }\end{array}$ & & $\begin{array}{l}\text { Postoperative myxe- } \\
\text { dema. Anemia, } 2 \text { yrs. }\end{array}$ \\
\hline 31 & 56 & $\begin{array}{l}70.0 \\
70.1\end{array}$ & $\begin{array}{l}1904 \\
1912\end{array}$ & +0.4 & 8 yrs. & $\begin{array}{l}\text { Good control } \\
\text { with diet alone }\end{array}$ & & $\begin{array}{l}\text { Hospitalized for head- } \\
\text { ache and diplopia. } \\
\text { Cerebral aneurysm }\end{array}$ \\
\hline
\end{tabular}

take. In most of these individuals, the increase in $\mathrm{Ke}$ could be ascribed to better regulation of the diabetes, or to replenishment of the body store of potassium by oral supplements or an adequate diet. There appeared to be no correlation between insulin dosage and the changes in $\mathrm{Ke}$ during the period of observation.

In 13 diabetics, the value for $\mathrm{Ke}$ did not change by more than 20 per cent. In 9 of these individuals, the diabetes was under good control; two required no insulin. Six patients were admitted for vascular complications resulting from dia- betes-coronary insufficiency or peripheral vascular disease, with gangrene of the lower extremities; one had acromegaly, and four were hospitalized for unrelated disease processes. In 3 patients, mild diabetes was diagnosed for the first time during hospitalization.

\section{COMMENT}

The results of the present study suggest that the presence or absence of a potassium deficit in diabetes can be correlated roughly with the relative adequacy of control of the diabetes. It is 
TABLE II-Continued

\begin{tabular}{|c|c|c|c|c|c|c|c|c|}
\hline Patient & Age & Weight & $\mathbf{K e}$ & $\begin{array}{l}\text { Change } \\
\text { in Ke }\end{array}$ & $\begin{array}{l}\text { Duration of } \\
\text { diabetes }\end{array}$ & State of disease & Complications & Incidental diseases \\
\hline & & Kg. & $\left(m E_{q .}\right)$ & $\%$ & \multicolumn{2}{|c|}{ Single determinations } & & \\
\hline 32 & - & 45.6 & 679 & & 7 yrs. & $\begin{array}{l}\text { Poor control, } \\
\text { marked wt. loss }\end{array}$ & $\begin{array}{l}\text { Neuropathy, renal } \\
\text { disease, furuncu- } \\
\text { losis }\end{array}$ & \\
\hline 33 & 55 & 55.9 & 2540 & & 4 yrs. & Good control & $\begin{array}{l}\text { Neurogenic } \\
\text { bladder }\end{array}$ & \\
\hline 34 & 25 & 43.6 & 2201 & & 9 yrs. & Erratic control & & Psychosis \\
\hline 35 & 18 & 72.0 & 1673 & & 3 yrs. & Fair control & & Obesity, amenorrhea \\
\hline 36 & 59 & 77.6 & 1530 & & $\begin{array}{l}\text { Diagnosed during } \\
\text { hospitalization }\end{array}$ & & & Obesity, hypertension \\
\hline 37 & 59 & 53.6 & 1092 & & 7 yrs. & $\begin{array}{l}\text { No recent wt. } \\
\text { loss }\end{array}$ & & $\begin{array}{l}\text { Admitted for coronary } \\
\text { artery disease and } \\
\text { angina }\end{array}$ \\
\hline 38 & 76 & 52.6 & 1662 & & 3 yrs. & 25 lbs. wt. loss & & Polycythemia vera \\
\hline 39 & 70 & 39.5 & 1139 & & 5 mos. & Poor control & & \\
\hline 40 & 67 & 45.9 & 1976 & & $\begin{array}{l}\text { Diagnosed during } \\
\text { hospitalization }\end{array}$ & $\begin{array}{l}50 \text { lbs. wt. loss } \\
\text { in } 15 \text { mos. }\end{array}$ & & Biliary cirrhosis \\
\hline 41 & 56 & 73.4 & 1750 & & 7 yrs. & Poor control & & $\begin{array}{l}\text { Hepatosplenomegaly, } \\
\text { cirrhosis, urinary tract } \\
\text { infection, chronic } \\
\text { cholecystitis }\end{array}$ \\
\hline 42 & 61 & 52.9 & 1317 & & 17 yrs. & Fair control & $\begin{array}{l}\text { Retinopathy, } \\
\text { neuropathy, } \\
\text { generalized } \\
\text { arteriosclerosis }\end{array}$ & $\begin{array}{l}\text { Admitted for gastro- } \\
\text { intestinal symptoms } \\
\text { and signs }\end{array}$ \\
\hline
\end{tabular}

All Ke determinations were performed at weekly intervals unless otherwise noted.

* Ke-1, initial determination.

$\uparrow \mathrm{K}-2$, determination after $\mathrm{KCl}, 3 \mathrm{Gm}$. daily, for 6 days.

Determination made 3 wks. after Ke-3.

$\ddagger \mathrm{Ke}-3$, determination 1 wk. after $\mathrm{Ke}-2$.

One month interval between 2 determinations.

Interval of 7 wks. between first 2 determinations.

recognized that the comparison of $\mathrm{Ke}$ values found in diabetics of various ages and normals of various ages, irrespective of difference in bodily habitus may not be valid. Many of the diabetics, in addition, had incidental diseases which in themselves may have influenced the $\mathrm{Ke}$ values.

No significant difference was found in the $\mathrm{Ke} /$ wt. value when the mean in the diabetic females was compared with that in normal females (6). It should be noted, however, that the mean in the normal from our laboratory is $9.2 \mathrm{mEq} . / \mathrm{kg}$. lower than that reported by Edelman (7). The range for this value reported by the latter, however, was greater than that in our series, suggesting that our data represent those from a more homogeneous group.

It has been previously shown that a potassium deficiency develops in the presence of a gross up- set of carbohydrate metabolism. Atchley, Loeb and Richards (1) showed that, upon acute insulin withdrawal from known diabetics, the loss of large amounts of potassium in the urine was associated with the hyperglycemia and glycosuria. Although the authors attributed this effect to dehydration (since potassium loss is known to occur in other conditions producing dehydration) it is possible that some of this loss may be due to glycogenolysis.

Tissue breakdown results in the loss of potassium. An insulin deficiency, by decreasing the rate of glucose catabolism, would reduce the total amount of energy available to the organism and might thus produce some tissue breakdown, with the consequent loss of nitrogen and potassium. However, recent studies by Danowski and his coworkers (2), who compared the loss of potassium 
EXCHANGEABLE POTASSIUM CONTENT OF NORMAL AND DIABETIC

MALES

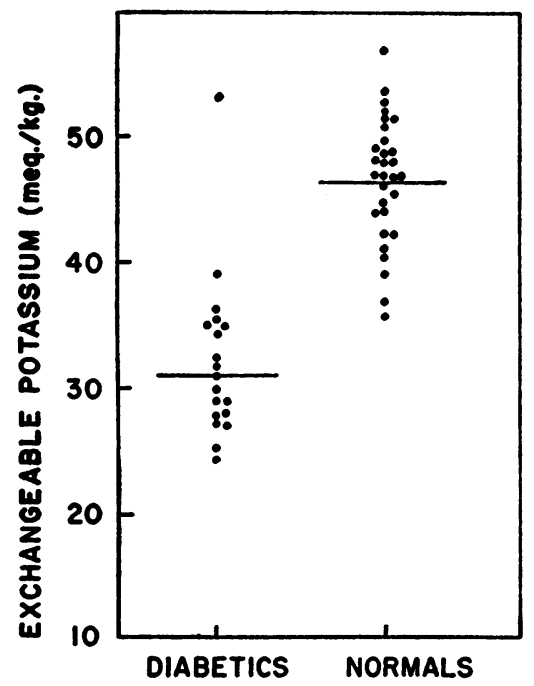

Fig. 1. The Mean Ke/Wt. in Normal Males is $46.3 \pm 4.31 \mathrm{MEQ./Kg.;} \mathrm{That} \mathrm{in} \mathrm{The} \mathrm{Diabetic} \mathrm{Males}$ WAS $31.4 \pm 7.25 \mathrm{MEQ} . / \mathrm{Kg}_{\mathrm{g}} . \overline{\mathrm{d}}=14.9, \mathrm{~s} \overline{\mathrm{d}}=1.79, \mathrm{t}=8.32$, $\mathbf{P}=<0.01$

and nitrogen in acidotic diabetic patients, have shown that the potassium loss is too great to be attributed solely to the breakdown of tissue. It therefore appears that, in certain diabetic states, an intracellular deficiency of potassium develops.

Certain biochemical studies suggest that such a deficiency of potassium might be expected in poorly regulated diabetes. The maintenance of the differential concentration of sodium and potassium between the extra- and intracellular phases against a diffusion gradient requires the expenditure of energy. It has been shown that, in the red blood cell, this energy can be derived from glucose catabolism (8). There is an intimate relationship between the metabolism of potassium and that of carbohydrate. Although many of the factors involved in carbohydrate metabolism are not well understood, the following facts are known: The deposition of glycogen increases the potassium content of liver cells (9), whereas glycogenolysis results in a loss of potassium from hepatic tissue; the hepatic deposition of glycogen produces a decrease in the concentration of potassium and phosphate in the plasma; glycogenolysis has an opposite effect. Lack of insulin decreases hepatic gly- cogen deposition, presumably through an effect on hexokinase.

In-vitro studies of carbohydrate metabolism have yielded evidences suggesting that potassium is necessary for several specific enzymatic reactions. The amount of potassium in the cell may regulate the rate of these reactions; or, conversely, the rate of the reactions may determine the amount of potassium in the cell. A deficit of potassium may impair the resynthesis of carbohydrates (10). If the deficiency is far advanced, tissue glycogenesis does not occur.

In animals placed on diets deficient in potassium, the potassium content of the muscles decreases and the sodium content increases. The adrenal glands of such animals show an increase in weight. This finding suggests that the adrenal hormones affect the sodium and potassium content of cells. The specific role of the adrenal gland in the regulation of sodium and potassium metabolism in diabetics is not known at the present time.

The loss of potassium from the body in diabetic subjects, then, appears to be related to the following four processes: 1) an excess of glycogenolysis over glycogenesis, 2) the breakdown of

\section{EXCHANGEABLE POTASSIUM CONTENT OF NORMAL AND DIABETIC FEMALES}

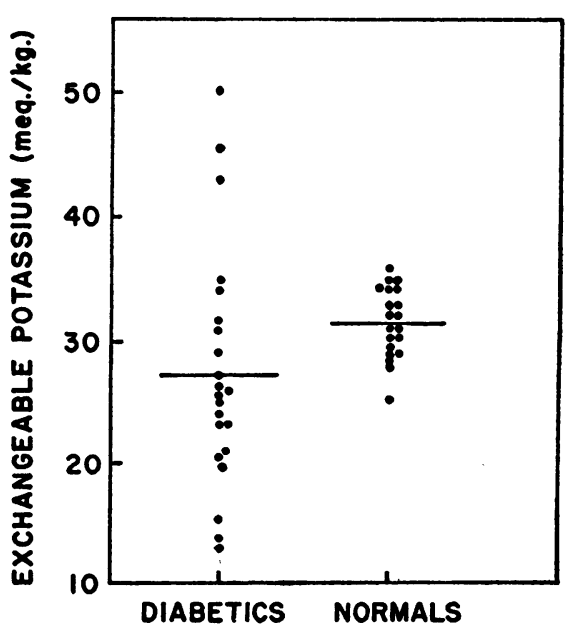

Fig. 2. The Mean Ke/Wt. in Normal Females is $31.5 \pm 2.90 \mathrm{ME} Q . /$ Kg. (6); That in the Diabetic FEmales Was $27.3 \pm 9.77$ mEQ./Kg. The Mean Difference, $4.2 \mathrm{mE} Q . / \mathrm{Kg}$., Was Not Statistically SignifiCANT 
tissue, 3) dehydration, and 4) disturbances in adrenal function.

The finding of a low $\mathrm{Ke}$ in a diabetic subject does not, however, necessarily indicate a metabolic deficiency of body potassium. Other possible explanations are: 1 ) decrease in body mass, 2) an increase in the relative fat content of the body, and 3) expansion of the extracellular fluid compartment (4). Retention of potassium, however, would not be expected to occur except with correction of an intracellular metabolic deficiency of potassium or with impaired renal function.

The results of the present study suggest that whenever carbohydrate metabolism is not properly controlled in diabetes mellitus, an occult intracellular deficit of potassium may develop. It is not possible to determine from the data on hand whether this deficiency is due to superimposed dehydration and acidosis or whether it is due to the uncontrolled diabetes per se. Such a deficit may be corrected by better regulation of the diabetes (which permits adequate intake of potassium in the food) and the administration of an oral supplement of potassium.

\section{SUMMARY AND CONCLUSIONS}

The exchangeable potassium content $(\mathrm{Ke})$ was determined by the radioactive isotopic technique in 42 unselected diabetic subjects. The initial $\mathrm{Ke}$ values were significantly lower in diabetic males than in normal male subjects. No significant difference was found in $\mathrm{Ke}$ between diabetic and normal female subjects.

Seven of the twenty subjects in whom serial determinations were performed showed an increase in $\mathrm{Ke}$ of more than 20 per cent. In general, the control of the diabetes was poorer in these seven subjects than in the 13 remaining individuals who did not show an increase in $\mathrm{Ke}$. The results suggest that the presence or absence of a potassium deficit in diabetes can be correlated roughly with the relative adequacy of control of the disease.

\section{REFERENCES}

1. Atchley, D. W., Loeb, R. F., Richards, D. W., Jr., Benedict, E. M., and Driscoll, M. E., On diabetic acidosis. A detailed study of electrolyte balances following the withdrawal and reestablishment of insulin therapy. J. Clin. Invest., 1933, 12, 297.

2. Danowski, T. S., Peters, J. H., Rathbun, J. C., Quashnock, J. M., and Greenman, L., Studies in diabetic acidosis and coma, with particular emphasis on the retention of administered potassium. J. Clin. Invest., 1949, 28, 1.

3. Corsa, L., Jr., Olney, J. M., Steenburg, R. W., Ball, M. R., and Moore, F. D., The measurement of exchangeable potassium in man by isotope dilution. J. Clin. Invest., 1950, 29, 1280.

4. Aikawa, J. K., Felts, J. H., Jr., Tyor, M. P., and Harrell, G. T., The exchangeable potassium content in disease states. J. Clin. Invest., 1952, 31, 743.

5. Aikawa, J. K., Fluid volumes and electrolyte concentrations in normal rabbits. Am. J. Physiol., 1950, 162, 695.

6. Aikawa, J. K., Harrell, G. T., and Eisenberg, B., The exchangeable potassium content of normal women. J. Clin. Invest., 1952, 31, 367.

7. Edelman, I. S., Olney, J. M., James, A. H., Brooks, L., and Moore, F. D., Body composition: studies in the human being by the dilution principle. Science, 1952, 115, 447.

8. Danowski, T. S., The transfer of potassium across the human blood cell membrane. J. Biol. Chem., 1941, 139, 693.

9. Fenn, W. O., The deposition of potassium and phosphate with glycogen in rat livers. J. Biol. Chem., 1939, 128, 297.

10. Gardner, L. I., Talbot, N. B., Cook, C. D., Berman, $H$., and Uribe, $C$., The effect of potassium deficiency on carbohydrate metabolism. J. Lab. \& Clin. Med., 1950, 35, 592. 